\title{
IL-10 plays an important role as an immune-modulator in the pathogenesis of atopic diseases
}

\author{
MINAKO KAWAMOTO, EIKO MATSUI, HIDEO KANEKO, TOSHIYUKI FUKAO, \\ TAKAHIDE TERAMOTO, KIMIKO KASAHARA and NAOMI KONDO \\ Department of Pediatrics, Graduate School of Medicine, Gifu University, Gifu, Japan
}

Received July 7, 2008; Accepted September 15, 2008

DOI: $10.3892 / \mathrm{mmr}+00000037$

\begin{abstract}
Interleukin (IL)-10 has anti-inflammatory activities in various immune reactions and plays an important role in the regulation of immune diseases. In the present study, we examined the role of IL-10 in atopic diseases. Peripheral blood mononuclear cells (PBMCs) from healthy control subjects, patients with atopic dermatitis and patients with bronchial asthma were cultured with lipopolysaccharide (LPS). The production of IL-10, IL-12 or IFN- $\gamma$ by PBMCs stimulated with LPS was measured. Next, we investigated whether the haplotype in the $I L-10$ gene promoter region had an effect on the production of IL-10 by PBMCs. PBMCs from patients were cultured with phytohemagglutinin, to which recombinant human IL-10 had been added. IL-12, IFN- $\gamma$ and IL-4 production by PBMCs was measured. B-lactoglobulin (BLG)-specific T cell clones were cultured with BLG peptide (P-17), antigen-presenting cells and recombinant human IL-10. The antigen-induced proliferation of the $\mathrm{T}$ cell clones and cytokine production were assayed. Results demonstrated that IL-10 production by LPS-stimulated PBMCs was lower in atopic patients than in healthy control subjects. Three different haplotypes in the $I L-10$ gene promoter region were detected. These haplotypes did not correlate with IL-10 production by PBMCs. IL-10 inhibited Th1 cytokine production by PBMCs, and also inhibited the antigen-induced proliferation of $\mathrm{T}$ cell clones and Th2 cytokine production. In conclusion, IL-10 inhibits both the production of Th1 and Th2 cytokines and the antigen-induced proliferation of $\mathrm{T}$ cell clones. Thus, IL-10
\end{abstract}

Correspondence to: Dr Minako Kawamoto, Department of Pediatrics, Graduate School of Medicine, Gifu University, 1-1 Yanagido, Gifu 501-1194, Japan

E-mail:mina@gifu-u.ac.jp

Abbreviations: $\mathrm{AD}$, atopic dermatitis; $\mathrm{BA}$, bronchial asthma; IL-10, interleukin-10; IL-12, interleukin-12; IFN- $\gamma$, interferon- $\gamma$; Th 1 , helper T cell type 1; Th2, helper T cell type 2; BLG, B-lactoglobulin; PBMCs, peripheral blood mononuclear cells

Key words: interleukin-10, atopic dermatitis, bronchial asthma, peripheral blood mononuclear cells, $\mathrm{T}$ cell clone, interleukin-10 gene modulates other cytokines and plays an important role as an immune-modulator in the pathogenesis of atopic diseases.

\section{Introduction}

Interleukin (IL)-10, which is a homodimeric cytokine produced by activated monocytes, macrophages, mast cells and T cells, is deeply involved in the regulation of inflammatory responses and immune reactions. IL-10 was originally described as an inhibitory factor produced by murine Th 2 cells that suppresses interferon- $\gamma$ (IFN- $\gamma)$ production by activated murine Th1 cells (1-3). Later, studies demonstrated IL-10 to be a potent inhibitor of monocyte and macrophage functions, suppressing the production of many pro-inflammatory cytokines and chemokines (4-7).

Several studies demonstrated that IL-10 has an important role in the pathogenesis of inflammatory bowel disease and autoimmune diseases, such as rheumatoid arthritis, systemic lupus erythematosus and multiple sclerosis $(8,9)$. These diseases are called Th1-mediated diseases, as Th1 cytokines play a central role in their inflammation.

Recently, studies have revealed that IL-10 is associated with the pathogenesis of Th2-mediated diseases, such as allergic diseases. Therefore, we investigated the involvement of IL-10 in allergic reactions.

\section{Materials and methods}

Atopic patients and control subjects. Twelve healthy control subjects and 31 patients with atopic disease were studied. The serum IgE levels and radioallergosorbent test (RAST) scores of 12 healthy control subjects, 12 patients with atopic dermatitis (AD) and 19 patients with bronchial asthma (BA) are listed in Table I. AD was diagnosed according to the criteria of Haniffin, and BA according to the criteria of The American Thoracic Society. The healthy control subjects had a negative history of atopic disease, and their serum IgE levels were within normal limits for their age. They were moreover healthy and free of any acute infections at blood sampling. The subjects were randomly selected through our hospital, and informed consent was obtained from all subjects or their parents.

Cell preparation. PBMCs were isolated from the heparinized blood samples of healthy control subjects and atopic patients by gradient centrifugation using Ficoll-Paque (Pharmacia, 
Uppsala, Sweden). PBMCs were suspended at a density of $10^{6} / \mathrm{ml}$ in RPMI-1640 medium supplemented with $10 \%$ heatinactive fetal calf serum, $2 \mathrm{mmol} / \mathrm{l} \mathrm{L}$-glutamine, $100 \mathrm{U} / \mathrm{ml}$ penicillin and $100 \mathrm{mg} / \mu 1$ streptomycin (10).

Cell culture. PBMCs $\left(10^{6} / \mathrm{ml}\right)$ were cultured with $1 \mu \mathrm{g} / \mathrm{ml}$ lipopolysaccharide (LPS) (Sigma, St. Louis, MO, USA) for $24 \mathrm{~h}$ in a volume of $1 \mathrm{ml}$ in a round-bottom tube (Falcon 2059, Becton Dickinson Labware, Lincoln Park, NJ, USA) at $37^{\circ} \mathrm{C}$ in a humidified atmosphere containing $5 \% \mathrm{CO}_{2}$.

PBMCs $\left(10^{6} / \mathrm{ml}\right)$ from one randomly selected healthy control subject, one AD patient and three BA patients were cultured with $10 \mu \mathrm{g} / \mathrm{ml}$ phytohemagglutinin (PHA) (Gibco BRL, Grand Island, NY, USA) or $1 \mu \mathrm{g} / \mathrm{ml} \mathrm{LPS} \mathrm{and} \mathrm{recom-}$ binant human IL-10 (Genzyme, Minneapolis, MN, USA) at $0.1,0.5,1,5,10,20$ or $100 \mathrm{ng} / \mathrm{ml}$ for $24 \mathrm{~h}$ in a volume of $1 \mathrm{ml}$ in a round-bottom tube.

Antigen-induced proliferative responses and cytokine production of BLG-specific T cell clones. B-lactoglobulin (BLG)specific $\mathrm{T}$ cell clones were used as described previously (11). The antigen-induced proliferation of the $\mathrm{T}$ cell clones was assayed by culturing $\mathrm{T}$ cells $\left(2 \times 10^{4} /\right.$ well) in 96 -well flatbottomed culture plates with the BLG peptide (P-17) and 3000 cGy-irradiated autologous PBMCs $\left(1.5 \times 10^{5} /\right.$ well) as antigen-presenting cells (APCs) and recombinant human IL-10, $(0.1,1,10$ or $100 \mathrm{ng} / \mathrm{ml})$ or recombinant human TGF- $\beta,(0.001$, $0.01,0.1,1$ or $10 \mathrm{ng} / \mathrm{ml})$. Cells were cultured for $72 \mathrm{~h}$ with $1 \mu \mathrm{Ci} /$ well of $\left[{ }^{3} \mathrm{H}\right] \mathrm{TdR}$ during the final 16 -h period, and the incorporated radioactivity was measured by liquid scintillation counting. To assay cytokine production, culture supernatants in 96-well flat-bottomed tubes were spun to remove cells after the cultures and were stored at $-80^{\circ} \mathrm{C}$ until used for assay.

Cytokine assays. IL-10 concentration was measured with a human IL-10 enzyme-linked immunosorbent assay (ELISA) kit (BioSource International, CA, USA) with a detection limit of $15.6 \mathrm{pg} / \mathrm{ml}$. IL-12 concentration was measured with a human IL-12 ELISA kit (BioSource International) with a detection limit of $7.81 \mathrm{pg} / \mathrm{ml}$. IFN- $\gamma$ concentration was measured with a human IFN- $\gamma$ ELISA kit (Ohtsuka, Tokyo, Japan) with a detection limit of $15.6 \mathrm{pg} / \mathrm{ml}$, and IL-4 concentration was measured with a human IL-4 ultrasensitive ELISA kit (BioSource International) with a detection limit of $0.39 \mathrm{pg} / \mathrm{ml}$. Lastly, IL-5 concentration was measured with a human IL-5 ELISA kit (Bio Source International) with a detection limit of $11.7 \mathrm{pg} / \mathrm{ml}$.

Detection of polymorphisms in the IL-10 gene. Genomic DNA was extracted from neutrophils with a Sepagene kit (Sanko Junyaku, Tokyo, Japan). The promoter region and five exons of the $I L-10$ gene (Gene Bank accession no. U16720) were amplified and sequenced using an ABI PRISM 377 DNA sequencer.

Statistical analyses. The significance of the differences between groups was analyzed using the Mann-Whitney U test. Probability (p) values $<0.05$ were considered statistically significant.
Table I. Clinical features of the 43 subjects.

\begin{tabular}{|c|c|c|c|c|c|c|}
\hline & \multirow{2}{*}{$\begin{array}{l}\text { Age } \\
\text { (years) }\end{array}$} & \multirow{2}{*}{ Gender } & \multirow{2}{*}{ Diagnosis } & \multirow{2}{*}{$\begin{array}{l}\text { Serum IgE } \\
(\mathrm{IU} / \mathrm{ml})\end{array}$} & \multicolumn{2}{|c|}{ RAST score } \\
\hline & & & & & HD & Derf \\
\hline \multicolumn{7}{|c|}{ Control subjects } \\
\hline 1 & 11 & M & Healthy & 5.7 & 0 & 0 \\
\hline 2 & 1 & M & Healthy & 5.9 & 0 & 0 \\
\hline 3 & 1 & $\mathrm{~F}$ & Healthy & 11.0 & 0 & 0 \\
\hline 4 & 1 & M & Healthy & 15.0 & 0 & 0 \\
\hline 5 & 1 & M & Healthy & 25.0 & 0 & 0 \\
\hline 6 & 1 & $\mathrm{~F}$ & Healthy & 29.1 & 0 & 1 \\
\hline 7 & 6 & $\mathrm{~F}$ & Healthy & 58.0 & 0 & 0 \\
\hline 8 & 5 & $\mathrm{~F}$ & Healthy & 70.0 & 0 & 0 \\
\hline 9 & 2 & M & Healthy & 72.0 & 0 & 0 \\
\hline 10 & 4 & $\mathrm{~F}$ & Healthy & 98.3 & 1 & 0 \\
\hline 11 & 5 & M & Healthy & 100.0 & 0 & 0 \\
\hline 12 & 1 & $\mathrm{~F}$ & Healthy & 110.0 & 0 & 0 \\
\hline \multicolumn{7}{|c|}{ Atopic patients } \\
\hline 1 & 1 & M & $\mathrm{AD}$ & 16.8 & 2 & 3 \\
\hline 2 & 0 & M & $\mathrm{AD}$ & 236.0 & 0 & 0 \\
\hline 3 & 3 & M & $\mathrm{AD}$ & $1,123.1$ & 5 & 6 \\
\hline 4 & 3 & $\mathrm{~F}$ & $\mathrm{AD}$ & $2,024.7$ & 6 & 6 \\
\hline 5 & 1 & M & $\mathrm{AD}$ & $2,586.5$ & 3 & 1 \\
\hline 6 & 13 & M & $\mathrm{AD}$ & $2,769.0$ & 3 & 3 \\
\hline 7 & 1 & M & $\mathrm{AD}$ & $3,476.0$ & 5 & 4 \\
\hline 8 & 4 & $\mathrm{~F}$ & $\mathrm{AD}$ & $3,782.6$ & 6 & 6 \\
\hline 9 & 3 & $\mathrm{~F}$ & $\mathrm{AD}$ & $4,514.1$ & 6 & 6 \\
\hline 10 & 6 & $\mathrm{~F}$ & $\mathrm{AD}$ & $5,500.0$ & 6 & 6 \\
\hline 11 & 5 & M & $\mathrm{AD}$ & $6,729.9$ & 6 & 6 \\
\hline 12 & 1 & $\mathrm{~F}$ & $\mathrm{AD}$ & $14,666.3$ & 3 & 3 \\
\hline 13 & 5 & M & BA & 114.6 & 4 & 5 \\
\hline 14 & 2 & $\mathrm{~F}$ & BA & 127.6 & 4 & 4 \\
\hline 15 & 2 & $\mathrm{~F}$ & BA & 148.0 & 4 & 4 \\
\hline 16 & 3 & $\mathrm{~F}$ & BA & 251.4 & 5 & 5 \\
\hline 17 & 7 & $\mathrm{~F}$ & BA & 267.7 & 3 & 4 \\
\hline 18 & 4 & M & BA & 300.0 & 0 & 0 \\
\hline 19 & 11 & M & BA & 451.0 & 5 & 5 \\
\hline 20 & 14 & $\mathrm{~F}$ & BA & 484.0 & 5 & 5 \\
\hline 21 & 10 & M & BA & 516.5 & 5 & 5 \\
\hline 22 & 9 & M & BA & 517.5 & 6 & 6 \\
\hline 23 & 3 & $\mathrm{~F}$ & BA & 545.2 & 6 & 6 \\
\hline 24 & 6 & M & BA & 616.3 & 1 & 1 \\
\hline 25 & 9 & M & BA & 669.9 & 3 & 3 \\
\hline 26 & 14 & M & BA & 839.0 & 5 & 5 \\
\hline 27 & 8 & M & BA & 907.0 & 6 & 6 \\
\hline 28 & 12 & $\mathrm{~F}$ & BA & $1,581.6$ & 2 & 2 \\
\hline 29 & 8 & M & BA & $1,700.0$ & 6 & 5 \\
\hline 30 & 13 & M & BA & $3,063.9$ & 6 & 6 \\
\hline 31 & 9 & $\mathrm{~F}$ & BA & $3,860.6$ & 3 & 4 \\
\hline
\end{tabular}

$\mathrm{AD}$, atopic dermatitis; BA, bronchial asthma. M, male; F, female. HD, house dust; Derf, Dermatofagoides farinae. 

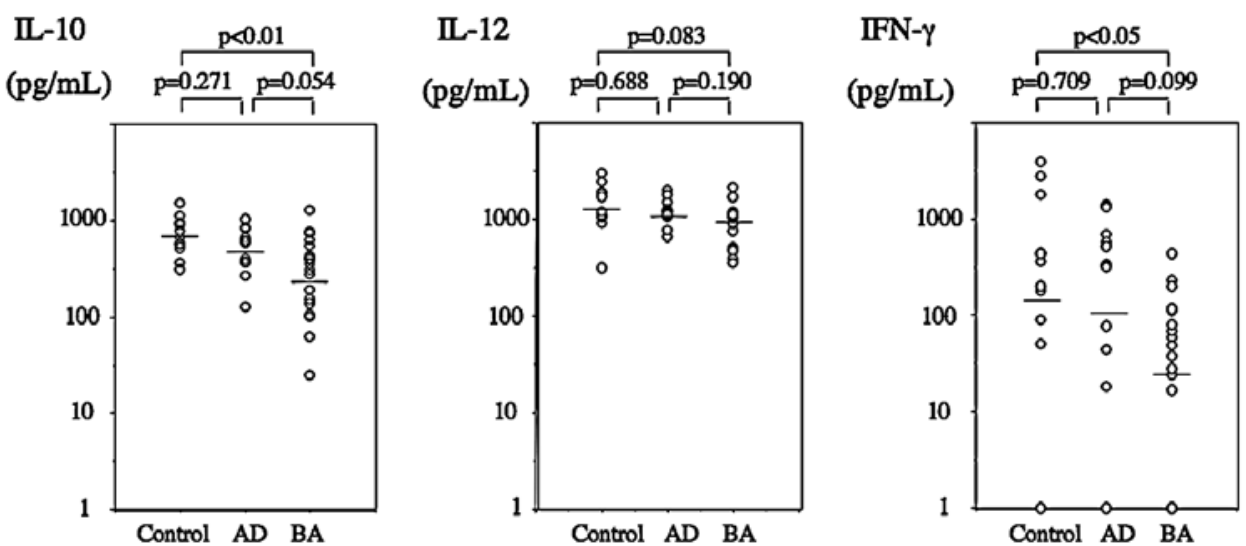

Figure 1. IL-10, IL-12 or IFN- $\gamma$ production by LPS-stimulated PBMCs in healthy control subjects $(n=12), A D(n=12)$ and BA patients $(n=19)$.

Table II. The prevalence of haplotypes in the $I L-10$ gene.

\begin{tabular}{llll}
\hline Haplotype & GCC & ACC & ATA \\
\hline Control $(n=10)$ & $0(0 \%)$ & $4(20.0 \%)$ & $16(80.0 \%)$ \\
AD $(n=10)$ & $0(0 \%)$ & $5(25.0 \%)$ & $15(75.0 \%)$ \\
BA $(\mathrm{n}=13)$ & $2(7.7 \%)$ & $7(26.9 \%)$ & $17(65.4 \%)$ \\
\hline
\end{tabular}

$\mathrm{AD}$, atopic dermatitis; $\mathrm{BA}$, bronchial asthma.

\section{Results}

IL-10 production by PBMCs in atopic patients and healthy control subjects. We studied IL-10 production by PBMCs in atopic patients and healthy control subjects. Twelve healthy control subjects, 12 patients with AD and 19 patients with BA were studied. IL-10, IL-12 and IFN- $\gamma$ production by LPSstimulated PBMCs was measured with ELISA kits. The features of the patients are summarized in Table I.

IL-10 production by PBMCs stimulated with LPS is shown in Fig. 1. IL-10 production was lower in atopic patients than in healthy control subjects. In particular, IL-10 production was lower in patients with BA (average, $275.4 \mathrm{pg} / \mathrm{ml} ; 1 \mathrm{SD}$ range, $102.3-741.3 \mathrm{pg} / \mathrm{ml}$ ) than in healthy control subjects (average, $691.8 \mathrm{pg} / \mathrm{ml} ; 1 \mathrm{SD}$ range, 446.7-1071.5 pg/ml) $(\mathrm{p}<0.01)$ (Fig. 1). IFN- $\gamma$ production was also lower in patients with BA than in healthy control subjects. IL-10, IL-12 and IFN- $\gamma$ production was lower in patients with $\mathrm{AD}$ than that in control subjects, but there was no statistically significant difference between the two groups when analyzed using the MannWhitney U test.

IL-10 gene polymorphisms and atopic diseases. The IL-10 gene from allergic patients and healthy control subjects was sequenced. We detected three polymorphisms in the $I L-10$ gene promoter region, $-1082(\mathrm{G} / \mathrm{A}),-819(\mathrm{C} / \mathrm{T})$ and $-592(\mathrm{C} / \mathrm{A})$ as previously reported $(12,13)$. These polymorphisms produced three different haplotypes, GCC, ACC and ATA.

We determined the prevalence of these haplotypes in the $I L-10$ gene in both allergic patients and healthy control subjects

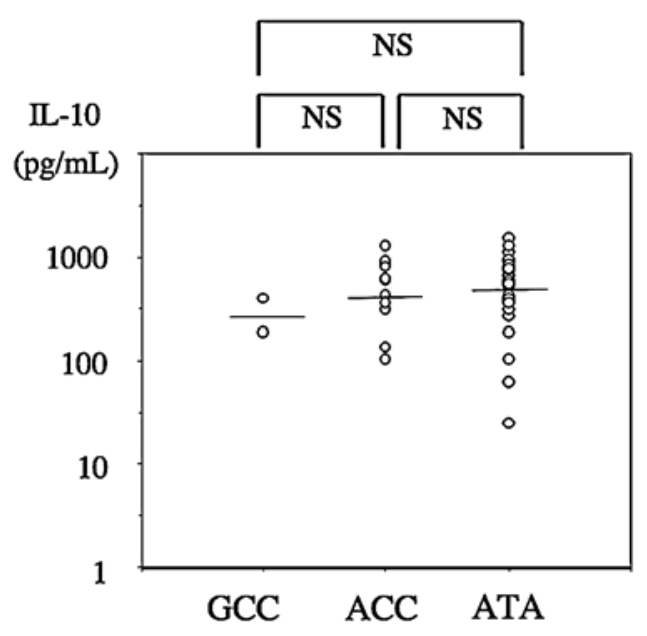

Figure 2. Relationship between the haplotype of the IL-10 gene promoter region and IL-10 production by LPS-stimulated PBMCs.

by direct sequencing (Table II). None of the healthy control subjects or AD patients had the GCC haplotype. Two of the BA patients had the GCC haplotype. Most of the healthy control subjects and atopic patients had the ATA haplotype.

Next, we investigated whether these polymorphisms were associated with the production of IL-10 by LPS-stimulated PBMCs. As shown in Fig. 2, these polymorphisms did not have an effect on IL-10 production by PBMCs in this study.

Effect of IL-10 on Th1 and Th2 cytokine production by PBMCs. The effect of IL-10 on Th1 and Th2 cytokine production in atopic patients was examined. IFN- $\gamma$ production by PBMCs stimulated with PHA was significantly inhibited by IL-10 in a dose-dependent manner (Fig. 3A). Similarly, IL-12 production by PBMCs stimulated with PHA was inhibited by IL-10 in a dose-dependent manner (Fig. 3B). IL-12 production by PBMCs stimulated with LPS was inhibited by IL-10 (data not shown). These data suggest that the production of Th1 cytokines such as IL-12 and IFN- $\gamma$ by PBMCs are directly inhibited by IL-10.

Furthermore, we investigated the effect of IL-10 on the production of the Th2 cytokine IL-4. IL-4 production by 
A.

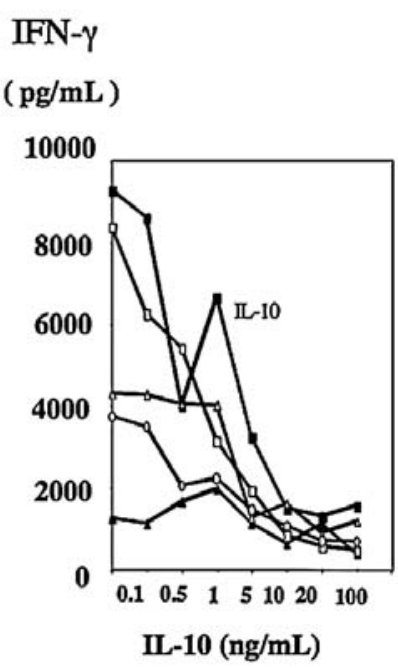

B.

IL-12

$(\mathrm{pg} / \mathrm{mL})$

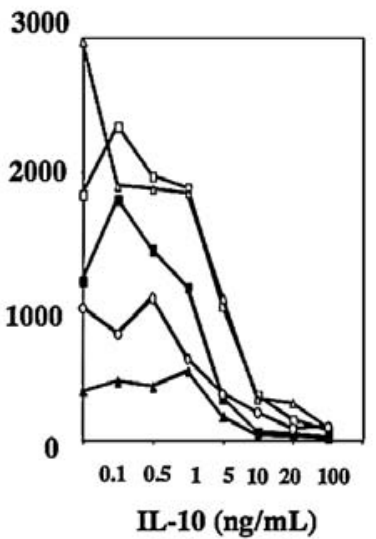

C.

$$
\begin{aligned}
& \mathrm{IL}-4 \\
& (\mathrm{pg} / \mathrm{mL})
\end{aligned}
$$

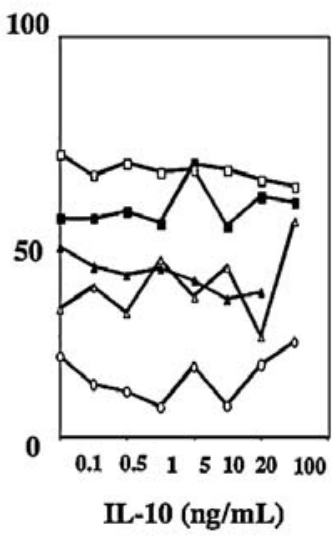

Figure 3. Effect of IL-10 on IL-12, IFN- $\gamma$ or IL-4 production by PHA-stimulated PBMCs in one randomly selected healthy control subject, one AD patient and three BA patients (control subject - - , AD patient - - -, BA patient $1-\square-$, BA patient $2-\triangle_{--}$, BA patient $3-0_{-}^{-}$). (A) IFN- $\gamma$ production by PHA-stimulated PBMCs was inhibited by IL-10 dose-dependently in one healthy control subject and three BA patients. In one AD patient, IFN- $\gamma$ production by PHAstimulated PBMCs was low and was not evaluated. (B) IL-12 production by PHA-stimulated PBMCs was inhibited by IL-10 dose-dependently in all patients. (C) IL-4 production by PHA-stimulated PBMCs was not affected by IL-10.
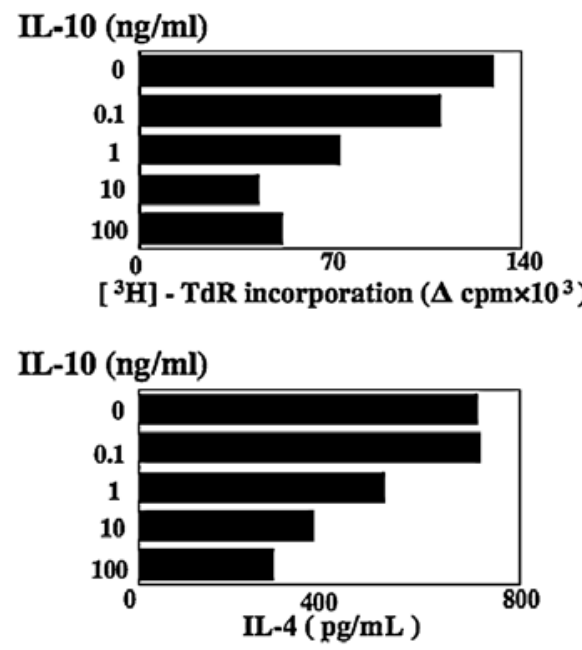

IL-10 (ng/ml)

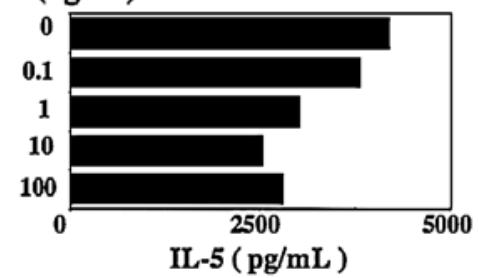

TGF- $\beta$ (ng/ml)

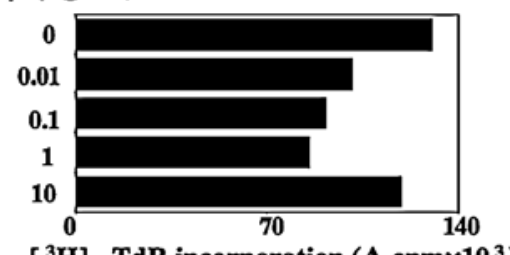

[ $\left.{ }^{3} \mathrm{H}\right]-\mathrm{TdR}$ incorporation $\left(\Delta \mathrm{cpm} \times 10^{3}\right)$

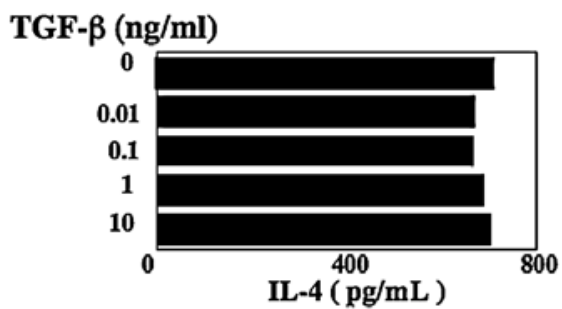

TGF- $\beta$ (ng/ml)

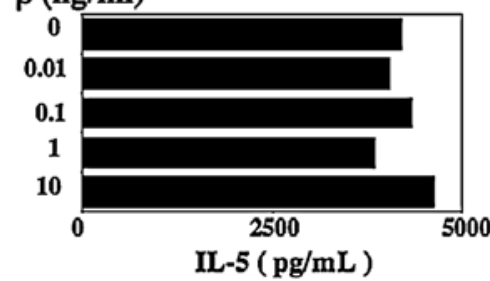

Figure 4. Antigen-induced proliferative responses and cytokine production of B-lactoglobulin (BLG)-specific T cell clones. IL-10 inhibited the BLG-specific antigen-induced proliferation of T cell clones. IL-10 also inhibited the production of IL-4 and IL-5 by T cell clones.

PBMCs stimulated with PHA did not change with the addition of IL-10 (Fig. 3C).

Effect of IL-10 on specific antigen-induced proliferation of $T$ cell clones. The effect of IL-10 on specific antigen-induced proliferation of $\mathrm{T}$ cell clones and Th2 cytokine production by $\mathrm{T}$ cell clones was examined. The BLG-specific antigen- induced proliferation of $\mathrm{T}$ cell clones was significantly inhibited by IL-10 in a dose-dependent manner (Fig. 4). In contrast, TGF- $\beta$ did not inhibit the proliferation of $\mathrm{T}$ cell clones.

Furthermore, IL-10 inhibited the production of the Th2 cytokines IL- 4 and IL- 5 by T cell clones in a dose-dependent manner (Fig. 4). 


\section{Discussion}

Immune responses generated by cytokines are essential to the development of allergic disease (14). IL-4, IL-5 and IL-13 produced by Th2 cells induce, prolong and amplify allergic responses by enhancing the production of $\operatorname{IgE}$ and the recruitment, growth and differentiation of eosinophils and mast cells. They also directly cause airway hyperreactivity in and of themselves. It has been suggested that Th2-mediated allergic diseases result from inadequate Th1 cytokine production. Our previous studies demonstrated that IL-12 and IFN- $\gamma$ play important roles in the regulation of IgE synthesis by $\mathrm{B}$ cells $(15,16)$.

IL-10 is an anti-inflammatory cytokine. Human IL-10, in contrast to murine IL-10 (which is primarily a Th2 product), is produced by both the Th1 and Th2 cells (17) as well as by mononuclear phagocytes, which may be its most important source (18). A role for IL-10 in the regulation of immune responses to allergens was first suggested by studies revealing that IL-10 inhibited cytokine production by eosinophils stimulated with LPS (19). Later, it was demonstrated that IL-10 might also inhibit the production of cytokines, such as TNF and IL-6, by stimulated mast cells $(20,21)$. IL-10 inhibits monocyte major histocompatibility complex-class (MHCclass II), B7.1 (CD80), B7.2 (CD88), intercellular adhesion molecule-1, and CD23 expression and accessory cell function (22). Monocytes pre-treated with IL-10 fail to induce specific antigen $\mathrm{T}$ cell proliferation.

In this study, IL-10 production by PBMCs in atopic patients, particularly BA patients, was significantly lower than in healthy control subjects. This might be explained by reduced IL-10 production, which was noted in the lungs of asthmatic patients as a result of a decreased gene expression level $(23,24)$.

Next, we investigated whether the difference in IL-10 production between healthy control subjects and atopic patients was due to a difference in the distribution of the haplotype in the $I L-10$ gene promoter region. In a previous study, the GCC/ GCC genotype was associated with higher production and the ATA haplotype with lower production of IL-10 by PBMCs compared with other genotypes. However, none of our subjects had the GCC/GCC genotype. Most of the healthy control subjects and atopic patients had the ATA haplotype. Two of the BA patients had the GCC haplotype. IL-10 production by PBMCs was not affected by these haplotypes of the $I L-10$ gene promoter region. Lim et al reported that the IL-10 haplotype has a role in determining disease severity, but does not seem to be important to disease susceptibility (12). More studies are required to clarify these points.

Lastly, we investigated the effect of IL-10 on the Th1 or Th 2 cytokines. In this study, IFN- $\gamma$ and IL-12 production by PBMCs stimulated with PHA were inhibited by IL-10. IL-12 production by PBMCs stimulated with LPS was also inhibited by IL-10. These data suggest that IL-10 is an inhibitor of Th1 cytokines. Moreover, IL-10 inhibited the antigen-induced proliferation of $\mathrm{T}$ cell clones and $\mathrm{Th} 2$ cytokine production by $\mathrm{T}$ cell clones. Previous studies have demonstrated that IL-10 inhibits cytokine production and the proliferation of $\mathrm{CD}^{+} \mathrm{T}$ cells and $\mathrm{T}$ cell clones via downregulatory effects on APC function $(2,25)$. In addition, IL-10 directly affects the function of T cells and inhibits IL-4 and
IL-5 production depending on activation conditions (26). It is reported that IL-10 production by regulatory $\mathrm{T}$ cells $\left(\mathrm{CD}^{+}{ }^{+}\right.$ $\mathrm{CD} 25^{+} \mathrm{T}$ cells) plays an important role in the regulation of allergies by inhibiting Th0, Th1 and Th2 cells $(27,28)$. Recently, it was reported that IL-10 and IL-13R $\alpha 2$ coordinatedly suppressed Th2-mediated inflammation and pathology, respectively (29).

IL-10 could play a critical role in the pathogenesis of atopic diseases and is a modulator of Th1 and Th2 cytokines. However, further research into the function of IL-10 is required.

\section{References}

1. Fiorentino DF, Bond MW and Mosmann TR: Two types of mouse T helper cell. IV. Th2 clones secrete a factor that inhibits cytokine production by Th1 clones. J Exp Med 170: 2081-2095, 1989.

2. Fiorentino DF, Zlotnik A, Vieira P, Mosmann TR, Howard M, Moore KW and O'Garra A: IL-10 acts on the antigen-presenting cell to inhibit cytokine production by Th1 cells. J Immunol 146: 3444-3451, 1991.

3. D'Andrea A, Aste-Amezaga M, Valiante NM, Ma X, Kubin M and Trinchieri G: Interleukin 10 (IL-10) inhibits human lymphocyte interferon $-\gamma$ production by suppressing natural killer cell stimulatory factor/IL-12 synthesis in accessory cells. J Exp Med 178: 1041-1048, 1993.

4. Firentino DF, Zlotnik A, Mosmann TR, Howard M and O'Garra A: IL-10 inhibits cytokine production by activated macrophages. J Immunol 147: 3815-3822, 1991.

5. Gruber MF, Williams CC and Gerrard TL: Macrophage-colonystimulating factor expression by anti-CD45 stimulated human monocytes is transcriptionally up-regulated by IL-1 beta and inhibited by IL-4 and IL-10. J Immunol 152: 1354-1361, 1994.

6. Marfaing-Koka A, Maravic M, Humbert M, Galanaud P and Emilie D: Contrasting effects of IL-4, IL-10 and corticosteroids on RANTES production by human monocytes. Int Immunol 8: 1587-1594, 1996.

7. Kopydlowski KM, Salkowski CA, Cody MJ, van Rooijen N, Major J, Hamilton TA and Vogel SN: Regulation of macrophage chemokine expression by lipopolysaccharide in vitro and in vivo. J Immunol 163: 1537-1544, 1999.

8. Gasche C, Bakos S, Dejaco C, Tillinger W, Zakeri S and Reinisch W: IL-10 secretion and sensitivity in normal human intestine and inflammatory bowel disease. J Clin Immunol 20: 362-370, 2000.

9. Grondal G, Gunnarsson I, Ronnelid J, Rogberg S, Klareskog L and Lundberg I: Cytokine production, serum levels and disease activity in systemic lupus erythematosus. Clin Exp Rheumatol 18: 565-570, 2000.

10. Kondo N, Fukutomi O, Agata H, Motoyoshi F, Shinoda S, Kobayashi Y, Kuwabara N, Kameyama T and Orii T: The role of $\mathrm{T}$ lymphocytes in patients with food-sensitive atopic dermatitis. J Allergy Clin Immunol 91: 658-668, 1993.

11. Sakaguchi H, Inoue R, Kaneko H, Watanabe M, Suzuki K, Kato Z, Matsushita S and Kondo N: Interaction among human leucocyte antigen-peptide-T cell receptor complexes in cow's milk allergy: the significance of human leucocyte antigen and $\mathrm{T}$ cell receptor-complementarity determining region 3 loops. Clin Exp Allergy 32: 762-770, 2002.

12. Lim S, Crawley E, Woo P and Barnes PJ: Haplotype associated with low interleukin-10 production in patients with severe asthma. Lancet 352: 113, 1998 .

13. Turner DM, Williams DM, Sankaran D, Lazarus M, Sinnott PJ and Hutchinson IV: An investigation of polymorphism in the interleukin-10 gene promoter. Eur J Immunogenet 24: 1-8, 1997.

14. Umetsu DT and DeKruyff RH: TH1 and TH2 $\mathrm{CD}^{+}{ }^{+}$cells in human allergic diseases. J Allergy Clin Immunol 100: 1-6, 1997.

15. Teramoto T, Fukao T, Tashita H, Inoue R, Kaneko H, Takemura M and Kondo N: Serum IgE level is negatively correlated with the ability of peripheral mononuclear cells to produce interferon gamma (IFN- $\gamma$ ): evidence of reduced expression of IFN- $\gamma$ mRNA in atopic patients. Clin Exp Allergy 28: 74-82, 1998.

16. Matsui E, Kaneko H, Teramoto T, Fukao T, Inoue R, Kasahara K, Takemura M, Seishima M and Kondo N: Reduced IFN-gamma production in response to IL-12 stimulation and/or reduced IL-12 production in atopic patients. Clin Exp Allergy 30: 1250-1256, 2000 
17. Del Prete G, De Carli M, Almerigogna F, Giudizi MG, Biagiotti R and Romagnani S: Human IL-10 is produced by both type 1 helper (Th1) and type 2 helper (Th2) T cell clones and inhibits their antigen-specific proliferation and cytokine production. $\mathrm{J}$ Immunol 150: 353-360, 1993.

18. Wanidworanun C and Strober W: Predominant role of tumor necrosis factor-alpha in human monocyte IL-10 synthesis. J Immunol 151: 6853-6861, 1993.

19. Takanaski S, Nonaka R, Xing Z, O'Byrne P, Dolovich J and Jordana M: Interleukin 10 inhibits lipopolysaccharide-induced survival and cytokine production by human peripheral blood eosinophils. J Exp Med 180: 711-715, 1994.

20. Arock M, Zuany-Amorim C, Singer M, Benhamou M and Pretolani M: Interleukin 10 inhibits cytokine generation from mast cells. Eur J Immunol 26: 166-170, 1997.

21. Marshall JS, Leal-Berumen I, Nielsen L, Glibetic M and Jordana M: Interleukin (IL)-10 inhibits long-term IL-6 production but not preformed mediator release from rat peritoneal mast cells. J Clin Invest 97: 1122-1128, 1996.

22. Ding L, Linsley PS, Huang LY, Germain RN and Shevach EM: IL-10 inhibits macrophage costimulatory activity by selectively inhibiting the up-regulation of B7 expression. J Immunol 151: 1224-1234, 1993

23. John M, Lim S, Seybold J, Jose P, Robichaud A, O'Connor B, Barnes PJ and Chung KF: Inhaled corticoastroids increase interleukin-10 but reduce macrophage inflammatory protein-1, granulocyte-macrophage colony-stimulating factor, and interferongammma release from alveolar macrophages in asthma. Am J Respir Crit Care Med 157: 256-262, 1998.
24. Borish L, Aarons A, Rumbyrt J, Cvietusa P, Negri J and Wenzel S: Interleukin-10 regulation in normal subjects and patients with asthma. J Allergy Clin Immunol 97: 1288-1296, 1996.

25. De Waal Malefyt R, Haanen J, Spits H, Roncarolo MG, Te Velde A, Figdor C, Johnson K, Kastelein R, Yssel H and De Vries JE: Interleukin 10 (IL-10) and viral IL-10 strongly reduce antigen-specific human $\mathrm{T}$ cell proliferation by diminishing the antigen-presenting capacity of monocytes via downregulation of class II major histocompatibility complex expression. J Exp Med 174: 915-924, 1991.

26. Schandene L, Alonso-Vega C, Willems F, Gerard C, Delvaux A, Velu T, Devos R, De Boer M and Goldman M: B7/CD28dependent IL-5 production by human resting T cells is inhibited by IL-10. J Immunol 152: 4368-4374, 1994.

27. Sakaguchi S: Regulatory T cells: mediating compromises between host and parasite. Nat Immunol 4: 10-11, 2003.

28. Bellinghausen I, Klostermann B, Knop J and Saloga J: Human $\mathrm{CD} 4^{+} \mathrm{CD} 25^{+} \mathrm{T}$ cells derived from the majority of atopic donors are able to suppress $\mathrm{TH} 1$ and $\mathrm{TH} 2$ cytokine production. J Allergy Clin Immunol 111: 862-868, 2003.

29. Wilson MS, Elnekave E, Mentink-Kane MM, Hodges MG, Pesce JT, Ramalingam TR, Thompson RW, Kamanaka M, Flavell RA, Keane-Myers A, Cheever AW and Wynn TA: IL-13 Ralpha2 and IL-10 coordinately suppress airway inflammation, airway-hyperreactivity, and fibrosis in mice. J Clin Invest 117: 2941-2951, 2007. 